\title{
Alternative Canons. Postmodern Canon-formation in Romanian Poetry
}

\section{Preliminary remarks}

As a "body of writings or other creative works that have been recognized as standard or authoritative" (Makaryk 1993: 514), a canon is a socio-cultural construct having an elite character and a legitimating function, more visible in the epoch of canonic differentiation. The semantic richness of the word canon, defined initially as a list, a rule, a law, a principle, then as a paradigm, a hierarchy, an episteme, could generate misunderstanding and manipulation. M. Martin (2000b: 5) refers to the paradox of the canon consisting in the fact of being simultaneously a principle of coagulation (the integration of the exception) and a principle of differentiation (the promotion of the exception).

According to $\mathrm{H}$. Bloom, the qualities that make an artistic work eligible for inclusion in a canon constitute its canonicity; it is given by originality, strangeness and therefore influence: "All canons, including our currently fashionable counter-canons are elitist" (Bloom 1994: 37). In fact, the canon is a space of convergence between valuation (which is central to the question of the canon) and the subjective "taste"; it needs a consensus of successive generations of readers, critics and educators. The term canon formation names the process whereby authors become recognized and highly esteemed as standard in a given culture. Bloom's Western canon denotes a canon of books, subjectively established, that have been the most important and influential in shaping the Western culture; as such, it includes "the greatest works of artistic merit". By School of Resentment Bloom designates the modern promoters of de-canonization; the canon extension by the inclusion of the peripheries equates, in fact, to its demolition. Bloom's historical rhetoric designates the Modern Age by the deprecating expression Chaotic Age. In Bloom's view, the canon is important to the theory of educational perennials and the development of "high culture". What in America was called canonical criticism, as opposed to "theory" was an

\footnotetext{
This research was supported by CNCSIS - UEFISCSU project PNII - IDEI, number 757/19.01.2009: Romanian Poetic Postmodernism. 1980-2010. A Semio-Pragmatic and Cognitive Approach. Director: Emilia Parpală. Code: 381 /2008.
} 
effort to influence curriculum and publishing. ${ }^{1}$ Fortunately, the imposition of an "essentially narrow vision of Western culture as a single coherent object, constructed of masterpieces built by geniuses" (Lauter 1991: 156) was constantly rejected, and the hierarchical ranking of books was revised by those who wish to abolish all canons.

The canon must pass the test of time: it implies canonization, de-canonization or re-canonization. The postmodern pluralism stimulates the multiplicity of alternative canons, which destabilize the oppressive, restrictive canonic order. The renewal and revitalization of literary forms could be accompanied by metacanonic reflections. The inflation of manifestoes, conceived as dissociating, argumentative, and self-legitimating documents, has favoured, in Romanian postmodern poetry, the coalescence of group poetics, polemics between generations and the ephemerality of literary conventions.

The concept postmodernism was defined either in a stylistic, or in an ideological manner. The first direction is concerned with the literary techniques (fragmentation, irony, the politics of palimpsestic representation, performativity, the revolution of the subject etc), while the second one prospects the extra-aesthetic values, namely the "continuous process of resistance against the dominant ideologies" (Hoover 1994: 16) ${ }^{2}$. Once accepted, the postmodern paradigm was diversified by its diffusion in transnational contexts. As a consequence, scholars speak about the necessity of an "invariant concept" - the "international postmodernism" (Bertens \& Fokkema 1997) consisting in "junctures and disjunctures" of an endless variety of "types and stereotypes" (Cornis-Pope \& Neubauer 2010), about a central hypercanon and its marginal counter-canons, following it like shadows (Damrosh 2003), about "many different canons and many different readerships" specific to the postmodern condition (Sell 2011: 1). The concept of "cultural symbiosis" (Talvet 2005) could be the best framework for the study of postmodern literary dynamics.

The objective of this article is to present the implementation of the Western postmodern canon in Romanian poetry and the internal dialogue between various, contradictory alternative groups. A large corpus of poems published

\footnotetext{
${ }^{1}$ In Romania, this issue was quasi absent. As an exception, see Alexandru Vakulovski's The Second Tiuk Manifesto. KLU Literature (Al 2-lea manifest KLU. Literatura KLU): "In order to save literature, the urgent, total disappearance of mandatory literary texts from institutions is needed. [...] We have to react in the right way to the aggression of programs and official literary canon: to recognize true literature wherever it may be" (Vakulovski 2002).

2 In Matei Călinescu's view, postmodern literature is "a product of an historical-political perspective from which some aspects of the contemporary writing can be questioned”. (Călinescu, 1996: 247).
} 
between 1980 and 2010 is used in order to argue how the "anxiety of influence" (Bloom 1997) was sublimated by Romanian postmodern poets into a creative stimulus. We due the canon-formation of postmodernism to the poets of the eighties, who transparently reshaped, after about three decades, postmodern American poetry; in addition to this, Russian (post)modernism and some internal Romanian sources are major points of reference. The first postmodernists' deconstructionism was "corrected" by the integrative poetics of the nineties generation; the rebellious generation of the Millennium, engaged in the dissolution of the Romanian postmodern canon, is in many aspects similar to vanguard experimentalism.

\section{Romanian debates on the (postmodern) canon}

In Romania, the canonical battle for imposing the poetry of the eighties has generated a theoretical debate on the canon, considered as yet another manifestation of the forms without substance: similar to the postmodernism without postmodernity, we had and we still have (de)canonizations without multiculturalism. ${ }^{3}$ The poet Alexandru Muşina doubted about the real postmodernism of the ' 80 s, calling it "the postmodernism at the gates of the Orient" (Muşina 2001: 115); in 1982, he contrasted the Romanian "socialist postmodernism" (ib.110) to his own "existential" project named "noul antropocentrism" (the new anthropocentrism).

The critical agenda was stimulated by the translation of Bloom's The Western Canon: the Books and School of the Ages, in 1998, and by the vogue of postmodernism, a style enthusiastically assumed by the generation of the eighties, thus performing a radical paradigm shift. The dispute was carried between the supporters of modern aestheticism ${ }^{4}$ and those who promoted the relativization of the canon on account of multiculturalism. A retrospect of the Romanian debates hosted by the reviews România Literară, Paradigma, Euresis, Caiete critice points out the recurrence of several questions: is there with us a postmodern counter-canon and, if yes, what does it signify - a style (an artistic

\footnotetext{
${ }^{3}$ Marius Chivu labels the discussions as "false debates" and argues that: "the theme of the canon was imported from the American space as a form of critical discourse without a literary-cultural substance. The way we had literary postmodernism without postmodernity, so we have an attempt of canonical debate in the absence of de-territorialization, of multiculturalism, of feminism, of cultural-political conflicts and militancies of a rasial, ethnic, religious and sexual nature". (Chivu 2007)

${ }^{4}$ In Romania, Bloom's aesthetic plea, evident in his canonical list, caused pro- and against views, presented in the bilingual anthology Canon si canonizare. (Mincu Bălu Butnaru 2003). 2003, Marin Mincu, Ion Bălu şi Leo Butnaru.
} 
typology), a literary tendency, a cultural moment? May we speak about the deaestheticization of the literary production? Was the aesthetic canon impure because of its being politically conditioned in communism? How could the discrimination of the East-European authors in Bloom's list be amended?

With Matei Călinescus, postmodernism is not a new, autonomous canon, but an appendix of modernism. In the article "For a speedy ending of the aesthetic canon", 1997, the semiotician Sorin Alexandrescu launched the anticanonical movement by posing the deadlock of the aesthetic canon and the methodological retardation of the Romanian criticism. Mircea Martin tackled the theoretical aspects of the canon: its relation to literary ideologies, genres and species (Martin 2000a), the existence of literatures which cannot be canonized (Martin 2000b), the canon shift (Martin 1999). By criticizing Bloom's list, he denounced its generous opening toward the representatives of the great languages, while the "small" literatures from East-Europe remained "non-homologated and non-fructified" (Martin 2001: 34). The Romanian theoretician considers that the problem of the canon, advanced in USA, is merely incipient in Eastern-Europe, where the modernist canon, although contested by the young generation, has not exhausted its resources (ib. 29).

As a whole, the Romanian contributions are preponderantly theoretical, uninterested in the educational politics of canon implementation; one can notice the richness and the divergence of opinions and the absence of some authoritative texts.

\section{The poets of the eighties in theoretical texts}

The meta-literary component plays an important role in a canon's existence. As the poets of the eighties have had an inadequate response from literary critics (see Parpală Afana 1994: 8-16), they interfered, with a remarkable theoretical appetite and self-awareness, and forced the de-canonization of modernism; the poets-theorists bring into attention a new concept - postmodernism - whereby they separate themselves from modernism and from the official totalitarian canon of socialist realism. Playfulness, irony, the parodic recycling, (meta)transitivity and dialogism become central categories in the new rhetoric.

\footnotetext{
${ }^{5}$ See the title of Matei Călinescu's book, Five Faces of Modernity: Modernism, Avant-Garde, Decadence, Kitsch, Postmodernism; postmodernism is the latest "face" of modernity (Călinescu 1987); his opinion is shared by Albert Gelpi: "The very fact that Postmodernism has not devised a name for itself indicates that it is what is left of Modernism" (Gelpi 1990).
} 
PARPALĂ

After about a decade, the critical canon of the eighties has been synthesized by the poet Mircea Cărtărescu in his doctoral thesis, Postmodernismul românesc (The Romanian Postmodernism), 1999. The theoretical relevance of the book is distorted by the fact that he presents the Romanian postmodernism as a monolithic, authoritative canon which is, in fact, an extrapolation of his own poetics. ${ }^{6}$ The definition of the postmodern poem indicates the preoccupation of the eighties for the stylistic novelty of literary techniques. ${ }^{7}$ The guillotine and the mechanical typewriter are symbols of the typographical era and, implicitly, of modernist suffering (Cărtărescu 1999b: 115-116). The counter-canon promoted in the name of the "realists", termed "biographic realism" (Cărtărescu 1999c: 119) or "the poetry of everyday life" (Muşina 1999a: 165), involves stylistic simplicity, orality, sincerity, and hedonism.

By taking into consideration the true here-and-now, Ioan Buduca wrote in the essay "Banda lui Möbius", 1984, about a "revolution of the subject" which replaced the impersonality of modern poetry; such a synthesis had already been done in the American poetry of the '50s and '60s, when confessional poetry and the Beat generation exposed the real biographical ethos, claiming a genuine community with reader(s). ${ }^{8}$ As the strip is a symbolic metaphor designating indeterminancy, continuity, and interference, Romulus Bucur's volume, Literatură, viață (Literature, Life), 1989, as well as Cărtărescu's volume Totul (Everything), 1985, and his original concept - "texistence" illustrate the contiguity life-literature. In order to exemplify "the power of mixture between literature and life”, Bogdan Ghiu's poem, Relația dintre noi (The relationship between us), 1989, recycles Saussure' two faced page, which is a scientific metaphor of the binary model of the sign.

While I'm writing, on the other side of the page (on the verso)

it's you. You're hiding and the sheet hides you. Writing, I (fore)see you I sense your shivering body, uneven, still, one with the earth

I touch you. You prevent me from writing correctly, nice. Why do you sit under

\footnotetext{
6 "Cărtărescu makes a description of his own poetry" (Muşina 2001: 103); "a critical excrescence of his autobiography as an artist" (Martin 30); "Cărtărescu seems to adjust the posmodern theory to his own poetics, rather than to the whole poetry of the eighties" (Andriescu 2005: 81).

7 "The standard-poem of the eighties tends to be long, narrative, agglutinated, with an orality well marked by special rhetorical effects, aggressive, (features specific to the Beat generation), but also ironical and self-ironical, imaginative to the point of onirism, playful, displaying an uncommon prosodic dexterity, finally impregnated with scholarly cultural allusions inserted by metatextual and self-referential devices" (Cărtărescu 1999a: 154).

8 Robert Lowell's Life Studies is a basic model adopted by the "transitive" poetry of the eighties in the process of renewing the poetic paradigm. (Crăciun 2002: 254).
} 
my sheet of paper, beyond it? Get out, come above, near me, instead of me. You support my sheet of paper. Our contact is just this sheet of paper. The text I'm writing is indebted (particularly) to the shape of your body. (Ghiu, The relation between us, 1989: 9. Translation: Rimona Afana) ${ }^{9}$

The page-sign represents an indestructible unity, comparable with the androgynous unity of the couple. The writing is humanized, because the subject has returned; as a signifier, writing is determined by the poet's lover, who represents the signified. The deconstruction of semiosis, the semiotic captivity, the poets' hesitation between real(ity) and the semiotic - all these show that the "real" and the "semiotic" are not antinomic entities. The sign becomes the figure of the text and, as S. Marcus has drawn attention to, the decoding of such texts "cannot be done without the help of semiotics" (Marcus 1986: 105). Hence, the necessity of a semiotic interpretation of the semiotic poetry of the eighties (Parpală Afana 1994).

As a promoter of new anthropocentrism, Muşina makes a reverence to classicism, to here-and-now-ism and declares that he is not a postmodernist (2001: 127). The rediscovery of the human being's wholeness, the contingency, the spirituality of the body direct the postmodern reform to the ontological and ideological level more than to the aesthetic one. The displacement of attention from the text to the reader, from "the stylistic intensity to the intensity of communication" (Muşina 1999b: 170) aims at the weakening of aesthetics in parallel with the humanization of poetry. ${ }^{10}$

Theoretical texts emphasise the reformative character of the generation, its anti-canonical action, that is, antimodernist. Compared to the meta-transitive rhetoric of the "realists", the "textualist" wing is less voluble", preferring to disguise the theoretical topics in the text. The poet's narcissism hyperbolised the conflictual principle in the process of postmodern canon formation.

\footnotetext{
9 În timp ce scriu, de cealaltă parte a paginii (pe verso) / eşti tu. Te ascunzi şi foaia te ascunde./ Scriind, te (pre)simt, / îți simt trupul tremurător, inegal, nemişcat, una cu pământul. / Te pipăi. Mă împiedici să scriu corect, frumos. De ce stai sub / foaia mea de hârtie, dincolo de ea? Ieşi afară, vino deasupra, / lângă mine, în locul meu! Îmi susții foaia de hârtie. Contactul / nostru e chiar această foaie de hârtie. Textul pe care îl scriu / se datorează (mai ales) reliefului trupului tău. (Ghiu, Legătura dintre noi, $1989: 9$ ).

10 "Re-humanizing" poetry represents, now, its great chance, the chance to overcome mannerism towards a new "classicism". [...] An unlimited anthropocentrism". (Ib. 172)
} 


\section{The formation of the postmodern canon of the ' $80 \mathrm{~s}$}

The "relaxation" of the modern canon has favoured the emergence of a postmodern anti-canon and subsequently its premature canonization. In Romania, postmodernism was imported in its Western variants and became the identity element of the groups which coagulated in literary circles and named themselves, with an unprecedented self-consciousness - the generation of the eighties. From a genetic point of view, three sources co-operated on the formation of the Romanian poetic postmodern proto-canon: the aesthetic modern canon, coexistent with the national-communist one and the contribution of Western counter-culture (Cernat 2002). Radu Andriescu (2005) speaks about the convergence of three cultural models: American postmodernism, Russian postmodernism and Romanian modernism, especially the avant-garde.

In theory as well as in the literary practice the relations with the Western canon have been explicitly assumed as a necessary synchronisation (not an imitation), isomorphous with the new sensitivity, vision and evolution of Romanian post-war poetry. In the name of the "realist" nucleus from Bucharest, Cărtărescu acknowledged the influence of American poetry, prevalently the Beat generation: the confessional poetry of Lowell and O'Hara's Personism which launched the vogue of biographical poetry. Therefore the masters of his generation are: Allen Ginsberg, Lawrence Ferlinghetti, Robert Lowell, ${ }^{11}$ Frank O'Hara, Gregory Corso etc. (Cărtărescu 1999a: 150) The poet also mentioned the Russian "noisy" poetry and the German contestant poets; he does not mention the American Language poetry as a virtual source for the "textualists". In fact, this filiation is more visible with the nineties, in C. Dobrescu's volume Deadevă, 1998.

In Occidentul (The West), Cărtărescu thematises the clash between the EastEuropean periphery and the American splendour of the Western canon. His self-ironical confession stages the ravaging consequences which the confrontation has upon a famous poet from a small culture. Reflected in the Western mirror, the narcissist author laments his changes into a counter-image: a litotic ethos, exhausted, hopeless, self-annihilated.

\footnotetext{
${ }^{11}$ Carmen Popescu (2011: 21) has noticed "a complex relation of palimpsest" between A. Bodiu's volume Studii pe viață şi pe moarte (Studies on Life and Death), 2000, and Lowell's Life studies, 1959, the allusion being visible in the paratext.
} 
oh, my world is no more!

my world is no more!

my stinky world in which I meant something.

I, mircea cartarescu, am nobody in the new world

there are 1038 mircea cartarescus here

and people 1038 times better than me

there are books here better than everything I've ever done

and women who couldn't care less about them.

The West opened my eyes and banged my head against the upper doorframe I leave to others what my life has been until today.

so that others believe in what I once believed.

so that others love what I once loved.

I can't anymore,

can't anymore, can't anymore.

(Cărtărescu, The West, 2007. Translation: Cristina Hanganu-Bresch) $)^{12}$

Further on, Cărtărescu denounces "the great literature", "too big, suffocated in its own fat". The defiance of high modern culture, by using the strategy of retraction (palinode), is a typical gesture for the postmodern spirit. The poet escapes the constraints of the poetic function and formulates, according to the Western postmodern canon ${ }^{13}$, the poetics of anti-poetic poetry.

and poetry? I feel like the last Mohican

ridiculous like Denver the dinosaur

the best poetry is the bearable poetry

nothing else: just bearable.

we made good poetry for ten years

without knowing what bad poetry we were making.

we made grand literature, and now we understand

that it cannot go through the door, precisely because it's big,

too big, suffocated in its own fat.

\footnotetext{
12 oh, lumea mea nu mai există! / lumea mea nu mai există! / lumea mea împuțită în care însemnam ceva. / eu, mircea cărtărescu, sânt nimeni în lumea cea nouă / există 1038 mircea cărtărescu aici / şi ființe de 1038 de ori mai bune / există cărți aici mai bune decât tot ce am făcut vreodată / şi femei cărora li se rupe de ele. / [...] Occidentul mi-a deschis ochii şi m-a dat cu capul de pragul de sus. / las altora ce a fost viața mea până azi. / să creadă alţii în ce am crezut eu. / să iubească alții ce am iubit eu. / eu nu mai pot. / nu mai pot, nu mai pot. (Cărtărescu, Occidentul, 2007).

${ }^{13}$ See O'Hara's Personism: A Manifesto, 1959: „The poem is at last between two persons instead of two pages. In all modesty, I confess that it may be the death of literature as we know it" (see Ford 2008: 247-248).
} 
PARPALĂ

this poem is not really a poem either

for only what is not poetry

can endure as poetry

only what is not poetry. (Ib. 2007) ${ }^{14}$

The disengagement with complexes, with the fear of the West has inspired other pastiches of Ginsberg' famous poem, America - Intrarea in NATO (Entering NATO) by Augustin Pop, Vestul, Vestul (The West, the West) by Ioan Stratan, and the "anti-patriotic" poem România by Marius Ianuş, dedicated to Ginsberg. In approaching the same topic, Gheorghe Iova has interfered the strategy of retractation ("I don't have much to say about Romania") with the textualist performative rhetoric; the text is nothing but writing, here and now, from the left to the right, on a horizontal support ("attention until the right margin of the text"):

I don't have much to say about Romania

The Romanian people or the like/or things alike

Indicative words

As what I know is known one

Or from the texts

Of all state institutions

[...] me given and taken as example me

I have nothing to say to strangers about all alongside

said Romania blank two because

I'm not a political spokesman

The little to be said attention until the right margin of the text (Iova, $^{* * *}$ 1998: 128. Translation: Rimona Afana) ${ }^{15}$

\footnotetext{
${ }^{14}$ iar poezia? mă simt ca ultimul mohican / ridicol asemeni dinozaurului Denver. / poezia cea mai bună e poezia suportabilă, / nimic altceva: doar suportabilă. / noi am făcut zece ani poezie bună / fără să ştim ce poezie proastă am făcut. / am făcut literatură mare, şi acum înțelegem / că ea nu poate trece de prag, tocmai fiindcă e mare, / prea mare, sufocată de grăsimea ei. / nici poemu-ăsta nu-i poezie / căci doar ce nu e poezie / mai poate rezista ca poezie / doar ce nu poate fi poezie. (Ib. 2007)

${ }^{15} \mathrm{~N}$-am prea multe de spus despre România / poporul român şi alte asemenea / cuvinte indicatoare / pentru că ceea ce ştiu este cunoscut unu / fie din textele / tuturor instituțiilor țării / [...] eu dat şi luat de exemplu eu /eu nu am nimic de spus străinilor despre toate de pe lângă / zis România blanc doi întrucât / nu sunt un purtător de cuvânt politic / puținul de zis atenție până la marginea din dreapta a textului. (Iova, ${ }^{* * *}$ 1998: 128).
} 
Inspired by French poststructuralism, Romanian textualism was a subversive experiment with the purpose of eluding the official, national-communist canon.

Is there a canon of the Romanian Postmodern poetry of the eighties? Romulus Bucur (2000: 11) answers affirmatively and states that it is a selfcanonization; the essayist and novelist Gh. Crăciun wrote about a "transitive canon" of the eighties (2009: 198). Even for the post-postmodernist contestants, the eighties are the most powerful group of writers existing today.

The often blamed decade criterion of classification (the poets of the eighties, nineties and the poets of the two thousands/of the Millennium) suggests that the invariant label of "postmodernism" was attached to a heterogeneous poetic reality. If the generation of the eighties has had "the most coherent and systematic generational politics through the legitimizing agent of postmodernism" (Cernat 2002), the pseudo-generation of the nineties has excelled in a "hermetic, pluralist" poetics (Braga 2010), whereas the poets of the Millenium manifest themselves in a "hedonist, Dionysian, and experimentalist" manner (Mincu 2004). By admitting the postmodern pluricentrism, Corin Braga focuses on the opposition between two types of concepts: the post-structuralist fragmentation and the hermetic integration, respectively the difference between the ' 80 s and the ' 90 s generation.

The collective portrait of the eighties displays some alternative canons. While Cărtărescu (1999a: 99;145; 372) described the Romanian poetic postmodernism as formed by a nucleus composed by two directions (a "realist" /"biographical" poetics of contingency and a "textualist" poetics) and two marginal directions („minimalism and neoexpresionism”), Ioan Bogdan Lefter (2005: 134-135) distinguished three sub-canons: the prosaics, the conceptualists and the moralists; every direction is accompanied by its stylistic properties and canonical "list".

I draw attention to the fact that the "biographic prosaism" (Cărtărescu 1999d) of those who carried down the poetry in the street wouldn't be discussed in extraliterary terms of "the real" or "the reality", but as an emergence of the referential and phatic function of poetry. The "real" of the ' $80 \mathrm{~s}$ is not the reality as such but a semiotized referent, hostile or indifferent to human acts. Meta-transitivity is often accompanied by a rhetoric of referentiality, as in Nichita Danilov's poem, Ghilotina, where the external referent is perfectly symmetrical to the internal one, and this mirror effect is explainable by the guillotination of the outside world, that is textua(liza)tion (Parpală Afana 1994: 23-24). 


\section{The post-postmodern counter-canon.}

\section{The generation of the Millennium}

At almost a decade from the 1989 Revolution, in the late '90s, young poetry has performed another code shift, in its attempt to ascertain its own identity in opposition to the '80s textualism. We are talking about a poetry of crisis, assertive in avant-garde style, isomorphous with the socio-cultural paradigm and paradoxically centred on the thesis of poetry as a communication act.

The canonization of the poets of the eighties and nineties (they are studied by now in universities) has provoked the violent contra-reaction of the young poets of the Millennium, who asserted themselves polemically, as a reply to the institutionalization of literary conventions; hence, the interest in the translation from the form of the poem towards its content and effect. A nihilistic radicalism determines the poets of the Millenium to proclaim, in contrast with the sclerosis of the eighties poetics, the authenticity of the new discourse, the power of the context and the fluency of communication channels. ${ }^{16}$

Marin Mincu (2004: I-VI), an enthusiastic promoter of the new "wave" of the poets of the "Millennium", remarked the violent break, the basic need for communication, the concern for retrieving the subject of writing, the discursive fracture, the search for authenticity, the exorcising of obscenity, the visceralising of autobiography. Igor Mocanu, referring to the anthology no longer poetry: new Romanian Poetry (by David Morley and Leonard-Daniel Aldea - the real name of poet Adrian Urmanov), has found the following general characteristics of the poetics of the 2000s: extreme heterogeneity, the teleological function of the poetic form and a poetics of contingency. We should add, as an individual note of the poets of the 2000s, the poetic "brotherhood" between Romanians and Moldavians; the "Chişinău commando" is singularized by the "hooligan" attitude, by colloquialism, by the "outraging" discourse.

The avant-garde of the 2000s has established the dependency of creation on the normative poetics of the group; it is an explosion of alternative "counter-

\footnotetext{
${ }^{16}$ Elena Vlădăreanu, a voice from inside, lays emphasis on the rhetoric of otherness: "[...] their literature is different. Because they speak differently. Their literature is born at the limit between commercial, existential and media elements. It does not acknowledge any rules; it does not impose any rules. Their writing is authentic, lively, a testimony of the incarnated being. [...] The poets of the eighties have stopped in a (warm, comfortable) space of the text [...]. They have installed a world, they have imagined a world. It isn't anybody's fault if today they don't say much to us, they don't persuade us any longer. The world we are building now does not have the same rustle of a cardboard universe. The world you find in our texts will seem familiar; this is where we all meet." (Vlădăreanu 2004: 327).
} 
canons" exposed in eccentric manifestoes and recycling polycentric models. Fracturism (Crudu \& Ianuş 1998), Utilitarianism (Urmanov 2003) and Club 8 (Lungu 1999) are the main paradigms of this "raw" realism, generating "warm poems" able to remake the connection between the real author and the real reader, between poetry and life. Devoid of national roots, Fracturism affiliates itself to a series of foreign poets: Ginsberg, Hlebnikov, cummings, Ashbery, the "new barbarians" - the Polish poets of the '90s. The manifesto is centered on anti-postmodernism ${ }^{17}$, anti-dogmatism, anarchism, authenticity, originality, sincerity, subjectivity. Derived from fracturism, the utilitarian poetics was articulated in terms of communication theory and it relies on the effect of resensibilization of the reader.

As "the canon and the counter-canon implicate and explain each other in a resentful manner" (Martin 2000b), we can observe, in spite of the idea of discontinuity and multiplication, which the canonical battles bring forth, some continuities among the recently canonized poets of the eighties and the 2000s contestants:

- the fracturist de-conceptualization carry out the '80s slogan on the authenticity of biographism; the confessional poetry - the communicative ideal of the utilitarians. Although the confessional pattern is present with the 2000s, there is not an influence of the Beat generation any more, but the prevalence of the cooperative principle.

- the rejection of the aesthetics of poetry (see the title of the anthology no longer poetry: new Romanian Poetry); for the "you" generation, the poem remains "between me and you", as O'Hara wanted:

this is not a poem

I don't write poems

I just want to be your good friend

that's all (Urmanov, utilitarian poems, 2003) ${ }^{18}$

- the deconstruction of the code shows the continuity with the vanguard. The hyperreality practiced by the ' 80 s becomes a fractured, asyntactical, minimalist referent. Crudu's empty lines, pointing out the graphic con-

\footnotetext{
17 "Fracturism is the first movement no longer connected to the poetry of the real, with the new anthropocentrism or with textualism. Finally, fracturism is the first model of a radical rupture with postmodernism”. (Crudu \& Ianuş 1998).

18 ăsta nu e un poem / eu nu scriu poeme / eu vreau să fiu prietenul tău bun / atâta tot (Urmanov, poeme utilitare, 2003).
} 
PARPALĂ

ventions of poetry, seem to illustrate Cărtărescu's assertion that "only what is not poetry / can endure as poetry":

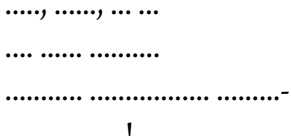

(Crudu, sonet de libov/libov sonnet $1994: 12$ )

- in spite of their noisy manifestoes, proclaiming the breaking off with postmodernism, the poets of the Millennium continue to exalt the antiaesthetic canon, a defining mark of their predecessors.

- while the textualists of the eighties based their semiotic discourse on dialogism and polyphony, the young post-postmodern poets bring forth the corporeality, the contingency and the communication with the reader. The tolerance towards kitsch manifested by postmodernism has opened the way towards the excessive poetic experimentation with slang and an obscene language connected to the exploration of corporeality, all in the name of sincerity. The thematisation of the body is an attempt of creating an erotic language for Romanian poetry.

We can notice that the Romanian literature of the 2000s is a preponderantly poetic phenomenon. By manifesting themselves in a neo-avant-garde manner, these young poets take heed of the death of postmodernism. In spite of specific concepts (authenticity, reactivity, subjectivity) and principles (sincerity, cooperation, the seduction of the reader, the isomorphism between poetry and media discourse), the poetry of the Millennium generation is controversial and sometimes unfaithful to its own theoretical postulates. We cannot but ascertain that the inconsistency of literary production contrasts with the noisy theoretical platforms.

\section{Final remarks}

In Romania, the debate on the canon and the corresponding literary practice, launched by the poets of the '80s, are the first forms of synchronizing with American and Russian literature; far from feeling defeated by the greatness of the American canon, as Cărtărescu claims, Romanian (post)postmodern poets are enthusiastic in affirming their alternative canons, suggesting the resistance to the "global relevance" of postmodernism in the context of an "accelerating 
globalisation" (Popescu 2011:21). The import of the Western canon, mimetic on the theoretical level, generated an organic phenomenon, a synthesis on the background of the valuable Romanian modernism and a process of differentiation on the background of the national-communist politics of stagnation. In spite of the pathetic rejection of modernism, performed by the "realists" of the '80s, the "textualist" alternative conceived subversive aesthetic strategies in order to avoid ideological implications. After 1990, the debates were mostly theoretical and underlined the obsolescence of the aesthetic canon.

We have to remark the productivity of the central postmodern canon and the germinative power of its "margins". Multiplicity, diversity and fusion of canons, reflecting a state of relaxation, witness an unprecedented literary dynamics and syncretism.

\section{References}

Alexandrescu, S. 1997. Pentru un mai grabnic sfârşit al canonului estetic. - Dilema, 245.

Alexandrescu, S. 1999. Privind inapoi, modernitatea. Bucureşti: Univers.

Alexandrescu, S. 2000. Identitate în ruptură. Bucureşti: Univers.

Andriescu, R. 2005. Paralelisme şi influențe culturale în lirica română actuală. Iaşi: Editura Universității “Alexandru Ioan Cuza”.

Bertens, H. \& Fokkema, D. 1997. International Postmodernism. Theory and Literary Practice. Amsterdam /Philadelphia: John Benjamins Publshing Company.

Bloom, H. 1994. The Western Canon: the Books and School of the Ages. New York: Harcourt Brace. [Bloom, H. 1998. Canonul occidental. Cărţile şi şcoala epocilor. Bucureşti: Editura Univers].

Bloom, H. 1997. The Anxiety of Influence: A Theory of Poetry. 2 edition. Oxford: Oxford University Press.

Bodiu, A. 2000. Mircea Cărtărescu. Monografie, antologie comentată, receptare critică. Braşov: Aula.

Braga, C. 2010. Le postmodernisme roumain. Querelle autour d'un concept. http://lett.ubbcluj.ro/ studii/2/10.html

Bucur, R. 2000. Poeți optzecişti (şi nu numai) în anii '90. Piteşti: Paralela 45.

Buduca, I. 1999. Banda lui Möbius. - Gh. Crăciun. 1999, 14-17.

Călinescu, M. 1987. Five Faces of Modernity: Modernism, Avant-Garde, Decadence, Kitsch, Postmodernism, Durham: Duke University Press. [Călinescu, M. 1996. Cinci fețe ale modernităţii: Modernism, Avangarda, Decadența, Kitschul şi Postmodernismul. Bucureşti: Editura Univers].

Cărtărescu, M. 1999a. Postmodernismul românesc. Bucureşti: Humanitas.

Cărtărescu, M. 1999b. Cuvinte împotriva maşinii de scris. - Gh. Crăciun. 1999, 115-118.

Cărtărescu, M. 1999c. Realismul poeziei tinere. - Gh. Crăciun. 1999, 119-121.

Cărtărescu, M. 1999d. Ce este biografismul? - Gh. Crăciun. 1999, 122-125.

Cernat, P. 2002. Dincolo de canonul estetic. - Observator cultural, 126. 
PARPALĂ

Chivu, M. 2007. Îmbrânceala canonică. - România literară, 8.

Cornis-Pope, M. \& Neubauer, J., eds. 2010. History of Literary Cultures of East-Central Europe. Junctures and Disjunctures in the $19^{\text {th }}$ and $20^{\text {th }}$ Centuries. Volume 4: Types and Stereotypes. Amsterdam/Philadelphia: John Benjamins Publshing Company.

Crăciun, Gh. 1999. Competiția continuă. Generația '80 in texte teoretice. Piteşti: Paralela 45.

Crăciun, Gh. 2002. Aisbergul poeziei moderne. Piteşti: Paralela 45.

Damrosh, D. 2003. What is World Literature? Princeton: Princeton University Press.

Gelpi, A. 1990. The Genealogy of Postmodernism: Contemporary American Poetry. The Southern Review, 517-541. http://writing.upenn.edu/ afilreis/88/gelpi.html

Lauter, P. 1991. Canons and Contexts. New York, Oxford: Oxford University Press.

Lefter, I. B. 2005. Flashback 1985: începutuile "noii poezii". Piteşti: Paralela 45.

Makaryk, I.J., ed. 1993. Encyclopedia of Contemporary Lietrary Theory. Approaches, Scholars,

Terms. Toronto: University of Toronto Press.

Marcus, S. 1986. Artă şi ştiință. Bucureşti: Editura Eminescu.

Martin, M. 1999. Schimbarea de canon. - România literară, 32.

Martin, M. 2000a. Canon şi decanonizare. - Observator cultural, 2.

Martin, M. 2000b. Despre canonul estetic. - România literară, 5.

Martin, M. 2001. Lista lui Bloom. - România literară, 24.

Mincu, M. \& Bălu, I. \& Butnaru, L., eds. 2003. Canon si canonizare. Constanța: Pontica.

Muşina, A. 1999a. Poezia cotidianului. - Gh. Crăciun. 1999, 165-168.

Muşina, A. 1999b. Poezia - o şansă... - Gh. Crăciun. 1999, 168-172.

Muşina, A. 2001. Sinapse. Braşov: Aula, 99-130.

Parpală Afana, E. 1994. Poezia semiotică. Promoția '80. Craiova: Editura Sitech.

Parpală, E., ed. 2011. Postmodernismul poetic românesc. O perspectivă semio-pragamtică şi cognitivă. Craiova: Editura Universitaria.

Popescu, C. 2011. Postmodernismul, o poetică globalizată (exemplul românesc). E. Parpală. 2011, 13-24.

Sell, R.D. 2011. Communicational Criticism. Studies in literature as dialogue. Amsterdam/ Philadelphia: John Benjamins Publshing Company.

Talvet, J. 2005. A Call for Cultural Symbiosis. Toronto: Guernica.

\section{Sources}

Bodiu, A. \& Bucur, R. \& Moarcăş, G., eds. 1999. Romanian Poets of the '80 and '90. A Concise Anthology. Pitești: Paralela 45.

Bodiu, A. 2000. Studii pe viață şi pe moarte. Piteşti: Paralela 45.

Cărtărescu, M. 2007. Occidentul/ The West. Trad. by C. Hanganu-Bresch.

Crudu, D. 1994. Falsul Dimitrie. Târgu Mureş: Arhipelag.

Crudu, D.\& Ianuş, M. 1998. Manifestul fracturist. - Monitorul de Braşov. http://asalt.tripod.com/a_086.htm

Ford, M., ed. 2008. Personism: A Manifesto. - Selected Poems by Frank O'Hara. New York: Knopf. pp 247-248.

Ghiu, B. 1989. Manualul autorului. Bucureşti: Cartea Românească. 
Alternative Canons. Postmodern Canon-formation in Romanian Poetry

Hoover, P., ed. 1994. Postmodern American Poetry. A Norton Anthology. New York/London: W.W. Norton \& Company.

Iova, Gh. 1998. 1973. Sintaxa libertăţii de a spune. Botoşani: Editura Axa.

Lungu, D. 1999. De ce un monguz vorbitor să fie mai prejos decît o pisică, sau ciorna unui Manifest. (Why Should a Speaking Mongoosian be Inferior to a Cat? or, the Draft of a Manifesto). - Respiro.

http://www.respiro.org/Issue5/poezie_manifestobilingual.htm

Mincu, M. 2004. Generația 2000 (Cenaclul Euridice). Antologie. Constanța: Pontica.

Muşina, A. 2002. Antologia poeziei generației 80. Ediția a II-a. Braşov: Editura Aula.

Urmanov, A. 2003. poeme utilitare. Constanța: Pontica.

Urmanov, A. \& Morley, D. 2007. no longer poetry: new romanian poetry. Warwick: Heaventree Press.

Vakulovski, A. 2002. Al 2-lea manifest KLU. Literatura KLU (The Second Tiuk Manifesto. KLU Literature). - Tiuk, 2.

http://tiuk.reea.net/index.php?option=com_content\&view=article\&id=1155

Vlădăreanu, E. 2004. Ia-ți târfa şi pleacă. - M. Mincu. 2004. pp 325-328. 